\title{
Spiritual Entrepreneurship in a Northern Landscape: Spirituality, Tourism and Politics
}

\author{
TRUDE FONNELAND \\ University of Tromsø
}

\begin{abstract}
A cultural turn in the economy has led to growth in what might be called 'spiritual entrepreneurship'. ${ }^{1}$ This term refers to entrepreneurs inspired by a New Age philosophy marketing spiritual values such as 'self-development', 'holism' and 'deep values'. To shed light on this type of enterprise, the article examines one of its practitioners; Esther Utsi at Polmakmoen Guesthouse in northern Norway. My focus is on how New Age spirituality is here localized, wrapped in local indigenous culture and landscape, and turned into a commodity with market value for both tourists and conference participants. The staging of spirituality simultaneously involves marketing a vacation destination to outsiders, and is also linked to the formation of a reimagined local identity, and incorporated into the redefinition of images and dreams about the northern region.
\end{abstract}

Keywords: spiritual entrepreneurship, New Age, tourism, indigenous spirituality, local reinvention

Polmakmoen Guesthouse is a tourist and conference center situated on the banks of the Tana River in Norway's northernmost county, Finnmark, often presented as the core area in Lapland and the heartland of the Sami culture. 'Come to Tana and the fairytale is yours' is the title of a promotional video on Polmakmoen Guesthouse's website. Polmakmoen is here presented as a place where guests can feel at home and in a different world at one and the same time. Words such as tranquillity, magic, and wild nature are central in the marketing and combine to create a picture of Polmakmoen as a resort far away from hectic everyday life; the website presents this place

1 What I call spiritual entrepreneurship is inspired by the term 'religious entrepreneurship' first proposed in a project proposal titled 'Religious Entrepreneurship and Religious Commercialisation' (2007) (Religiøst entreprenørskap og religiøs kommersialisering) by Lisbeth Mikalesson and Torunn Selberg at the Department of Archaeology, History, Culture and Religion, University of Bergen. 
as a land of fairytales, where your longings for peace and inner harmony will be fulfilled. ${ }^{2}$

Polmakmoen represents a tourism site that in many ways is unique and innovative in the northern Norwegian and perhaps also in a larger Norwegian context. The philosophy of the New Age market is here mixed with tourism and conference enterprises, offered both to spiritual seekers and the general public. The guest resort presents a vision of crossovers between religion, local development and tourism, combining local traditions with global trends. Polmakmoen Guesthouse is also more than a vacation destination - it is the hostess's own home, and represents an embodiment of her life projects and visions for the future.

In this article I will discuss the stories and images that are the focus of the Sami tourist resort Polmakmoen Guesthouse. I will explore what role religion, in the form of Sami indigenous spirituality, plays in the construction of this site, and focus on the manner in which religion is part of the commodity presented at Polmakmoen - how spirituality is produced, packaged and staged. I also discuss how one woman's religious experiences can be linked both to local and economic development, and to visions for new images of the northern region.

My analysis is based on my own visit to Polmakmoen in November 2010, and my meeting and interview with the hostess. ${ }^{3} \mathrm{I}$ also analyze the retreat's new homepage, which was launched just a month before my visit, 20.10.2010. This homepage contains pictures of the site, and information about how to get to Polmakmoen, about the municipality, and about conferences, healing and other available activities. The website's homepage also has a ten-minute long promotional video, made in 1998, which focuses on Sami culture, and presents the people of Polmak and their activities through the four seasons.

The article begins with a closer analysis of the term spiritual entrepreneurship, which I link to the rise of a cultural economy, and which counters traditional stereotypes of religious and economic activities as being in mutual opposition. As a point of departure for further discussion, I focus on Polmakmoen Guesthouse and ask how spirituality is displayed for tourists and conference participants. The hostess at Polmakmoen can be said to have put spirituality to work in unusual settings. In the article I present

2 http://www.polmakmoen-gjestegard.no/index.html, accessed 01.02.2011.

3 An interview is a social encounter and a situation where two or more people interact and where experiences are interpreted and meaning created. The knowledge embodied in this meeting is based on interaction. Knowledge and meaning have been created inter-subjectively between the researcher and the researched (Järvinen 2005). 
her visions for a new business economy and ask how spirituality is linked to the creation of new stories and new senses of the region.

\section{Spiritual Entrepreneurship - Magic of the Mix}

The period during which Polmakmoen Guesthouse was launched has been characterized as 'capitalism's summer of love' (Thrift 2006). It was a time of economic change. A whole new vocabulary about capitalism emerged, consisting of buzzwords like 'soft capitalism' (Ray \& Sayer 1999), 'virtual capitalism' (Dawson \& Foster 1996), the 'dream society' (Jensen 1999) and the 'experience economy' (Pine \& Gilmore 1999). The narrative of 'the New Economy' which developed during the 1990s was to influence both markets and businesses, and change people's visions and actions in many radical ways (Löfgren \& Willim 2006, 1). One of the striking characteristics of the period was the emphasis on creating new and unusual combinations crossovers and mixes, the concept of the 'experience economy' being but one example.

The experience economy encompasses all types of branding and is about engaging consumers through personal stories and images that are meant to give each individual customer access to a unique, memorable and extraordinary experience. In The Experience Economy (1999), Joseph B. Pine and James H. Gilmore see a significant change in contemporary consumers, who are no longer concerned only with buying goods and services, but who are increasingly looking for adventures that 'engage' the participants. In the future, Pine and Gilmore emphasize, the ability to create personal experiences will give companies and enterprises a sustainable competitive advantage, experiences being the hottest commodities the market has to offer (1999).

The ethnologist Orvar Löfgren (2003, 243-4) emphasizes that this 'New Economy' involves a process of culturalization in the ways in which production and consumption are developed and connected. He argues that at the same time as economic thinking colonizes everyday culture, the reverse is also true. Social and economic forms and activities are given a cultural form, and energy is invested in producing atmospheres, symbols, images, icons and auras.

These changes and turns in the economy also led to a growth in what I call 'spiritual enterprise' ventures: businesses where New Age spirituality is a central part of the product and of the marketing strategies. From its beginning in the 1970s, New Age was interpreted as a counter-cultural movement 
for hippies and other drop-outs. Today, however, New Age spirituality has become far more widespread and has moved from the fringes of culture to its mainstream (Hammer 2001; Kraft 2011). ${ }^{4}$ As a result, New Age spirituality is to be found in a wide range of sectors of society: in popular culture, in health care, and now also in parts of the tourist industry.

The introduction of New Age philosophy in some business circles is in line with a wider tendency to put spirituality to work to enhance productivity (Aupers \& Houtman 2006). These 'spiritual entrepreneurs' provide a valuable insight into a key perspective on religion in contemporary society, namely how religion adapts to consumer culture and its values. Words like 'spirit', 'holism', 'deep values' and 'self-development', which are central in New Age thinking, here appear as key terms in the production of unique experiences for consumption. In the tourist industry, this phenomenon can be recognized in the spa and wellness sector (see O'Dell 2005), in pilgrim tourism (see Kraft 2007; Bowman 2007; Selberg 2011; Stausberg 2011), in the new 'Slow Movement' related to the marketing of slow food and slow experiences (see Honoré 2004), and in indigenous tourism (see Stausberg 2011; Johnston 2006; Hinch 2004). In what way and to what degree spiritual entrepreneurs connect to New Age philosophy varies. It does not need to be their sole marketing basis. A combination of a variety of spiritual and secular offerings and services is probably more typical of entrepreneurs in the religious field, because a combination makes it easier to survive financially.

Many spiritual entrepreneurs work within niche markets with uncertain economic outlooks, where the values created are of a cultural, aesthetic or symbolic character rather than purely economic (see Hess 1993; Birch 1996; Mulcock 2001). The interaction between economic models for religious activities and religious meaning production is here central. Several religious entrepreneurs explicitly present themselves as businesses where you can find a combination of commercial interests with a vision of a life project that goes beyond the commercial.

With certain prominent exceptions, it is relatively rare in the research that the connection between religion and economics is thematized and prob-

4 The term New Age Spirituality can be seen in context with Christopher Partridge's concept of 'occulture'. Very briefly, occulture includes those often hidden, rejected and oppositional beliefs and practices associated with esotericism, theosophy, mysticism, New Age, paganism, and a range of other subcultural beliefs and practices (Partridge 2004, 68). Occulture is open for everyone and is used by people with different motivations, by popular culture's producers, by advertising agents as well as spiritual seekers. 
lematized. ${ }^{5}$ Guy Redden, however, has argued that the economic dimension is crucial to understanding the dynamics of New Age activities, and that the dissemination of religious alternatives happens quite literally in the market-place. The point is not, however, that New Age can be reduced to economics - that greed and profit is essential for those involved (Redden 2005). In using the term 'spiritual entrepreneur', my intention in this article is to align myself with the growing cadre of scholars who are challenging the traditional dualistic view of religion and economy as separate and distinct (see Partridge 2004; Redden 2005; Kraft 2011). Through the development of a new religious landscape, the institutional forms of religion are being reshaped, and the 'religious economy' is changing.

\section{A Tourism Destination takes Shape - Esther's Story}

We are now ready for a trip to northern Norway, to Polmak in Tana municipality, where the concept of spiritual entrepreneurship will be contextualized through an encounter with the hostess of Polmakmoen Guesthouse. On one of the last days with glimpses of sun before the dark season begins, I am off to Tana. After a two-hour drive from the nearest airport in Vadsø, I approach my target. In a desolate and sparsely-populated landscape covered in snow, three kilometers from the center of the municipality, I see a sign with the words Polmakmoen Guesthouse and turn into the courtyard.

Polmakmoen Guesthouse was formerly a farm. Today the guest resort consists of two main houses, an old and a new, both of which are used for accommodation and conferences when needed. Additionally, it has six traditional dwellings, 'gamme' or turf huts, equipped with modern conveniences, and a larger star-shaped gamme housing a restaurant, which is also used as a conference room. Guests can enjoy a wood-fired sauna, an outdoor bath tub and an Indian sweat lodge. Among the activities offered are salmon fishing in the Tana River, snowmobile tours, mountain hiking, healing inspired by Sami shamanism, and social gatherings with stories about local Sami culture and performances of the Sami 'yoik', a chanted folksong genre. ${ }^{6}$

Polmakmoen Guesthouse today employs two staff full-time: a general manager or hostess, and a person who participates in the domestic tasks like washing and cooking. The resort's income has gradually been increasing, and in 2010 it approached NOK two million.

5 One major exception, for example, is the sociologist Max Weber's theory on the relationship between the Puritan work ethic and the rise of Western capitalism (Weber 1930).

6 http://www.polmakmoen-gjestegard.no/index.html, accessed 01.02.2011. 
Esther Utsi, a Sami woman in her sixties, is the hostess at Polmakmoen Guesthouse. Polmakmoen used to be the home of her grandparents, which Esther took over in 1985. Here, in the early 20th century, Esther's grandmother started private overnight inn for clergy and other public officials visiting Polmak. The story has it that she refused to budge when the whole area of Neiden was burnt to the ground during the Second World War; and by doing so, she prevented her house from being set on fire by the German soldiers. As hostess at Polmakmoen Guesthouse, Esther is in many ways continuing her grandmother's life project, albeit in different and expanded forms.

The creation of a narrative about a product is a strong tool in the contemporary experience economy (Mossberg 2007, 321). In the context of tourism, such narratives are ways of encoding customers' reading of a place, and steering their perceptions of a culture as an attractive and unique 'experience package'. At Polmakmoen Guesthouse, Esther's personal life story plays a central part in the product that is being marketed. The main themes in the story are her Sami background, her spiritual calling to build a tourist resort and her receiving of the guesthouse's trademark.

Esther tells how she grew up in a Sami family. Her father was a reindeer herder and her mother took care of their farm and nine children, while her husband was away watching reindeer. She describes her parents as opposites, her mother representing a rational world concerned with the family's economy and well-being, and her father connected to the spirituality of nature and to Sami traditions. When he came home, he would tell Esther and her siblings stories about the gufihtar, 'the invisible people', and all the strange and mysterious things that happened to him and the herd while they were away. ${ }^{7}$ Esther clearly remembers the excitement she felt listening to him, and recounts how he communicated with the spiritual world of his forefathers and received messages from his spiritual helpers concerning the farm, his family and friends. Esther believes that she has inherited both her father's and her mother's qualities. In our interview, she says:

In the first 35 years of my life, I was guided by my mum's rational thinking, but after the age of 35 I came closer to the stories and experiences my dad had contributed. Alternative books started falling into my lap. I began reading these books and learned that we have spiritual helpers and that

7 The Sami word gufihtar is not directly translated by the term 'the invisible people'. Gufihtar in the Sami tradition are spirits connected to a specific location; a stone, a mountain or a lake. They had extraordinary powers and could affect people's lives in both good and bad ways. 
we can communicate and get information from them just as my father had told me - though the books used different words for it. But when it came to the point that my helpers told me that I should quit my job as chief of the welfare department in Tana municipality and begin to heal, and that I was to start a center here at Polmakmoen, it felt like a rather dramatic and scary life change, that I was not certain I could follow. (Esther interview 1, protocol page 1, my translation.)

For a time Esther had felt burnt-out in her work as director of the local welfare department. Her experience was that the welfare system was not functioning, and she saw that her clients suffered from this. Esther felt exhausted and powerless, and started reading alternative literature to find new ideas and answers. Esther describes this period in her life as a crossroads and as an opening in which adopting New Age perspectives allowed her to regain touch with her Sami ancestors. She also experienced contact with spiritual helpers among her Sami forefathers, such as her grandmother and her father. ${ }^{8}$

Twice these helpers had contacted Esther, delivering the same message each time. The third time was a turning point. Esther was on her way home on a Widerøe plane. The plane entered an air pocket, and dropped sharply, injuring Esther's neck. At the exact moment, her helper's message manifested itself for the third time. According to Sami traditions, a third message is also the last one the spirits will bring; Bente Alver emphasizes: 'If you relate to the spirits as a reality, there are no spirits coming the fourth time' (Alver 1999, 156, my translation). Being familiar with this tradition Esther says she finally recognized the seriousness of the message, and vowed to leave her job in Tana municipality, a safe and well-paid job she had held for eighteen years. By the summer of 1997, she had made the first steps in developing what would later be known as Polmakmoen Guesthouse. This story can also be seen as a 'call' narrative. It emphasizes Esther's experience of being chosen, and is interpreted as an injunction to use her special abilities for her fellows. Just like other 'call' narratives, the story is based on series of events that are connected and interpreted as a bid from 'outside' - from divine powers (Alver \& Selberg 1992, 72-4; Alver 2011, 137-8).

Standing in the yard at Polmakmoen, looking out over the large bare area she has been told to convert into an attractive tourist and conference

8 Within the New Age field, spiritual beings such as ancestors, souls, angels, ghosts and ascended masters are looked upon as spiritual helpers who have the power to guide, if a person is able to open herself up, and accept their guidance. 
destination, Esther feels anxiety about how to pay for all the necessary investment. Suddenly the calming voice of her grandmother fills the air. 'Ale moraš' it says - the Sami for 'leave your anxiety behind - do not worry'. From that day on the slogan 'ale moraš' became Esther's trademark, and the central content in everything she wishes to convey to her guests. Esther started marketing Polmakmoen as a place where visitors can let go of their anxiety, stress and worries, and found that there is a great need in society for this type of experience - the experience of spirituality, silence and tranquillity:

Trude: But when you market Polmakmoen, what do you choose to present as the core values of this place?

Esther: The main factor is that people should feel very harmonic and peaceful when they arrive here. I used to say that here, troubled kids sleep, and stubborn men turn into butter [laughter]. Something happens to people at Polmakmoen. It is the peace that does it first and foremost ... that visitors get an opportunity to seek inwards. So it is not only a physical rest, but you feel peaceful within yourself. I have seen what happens to people when they come here, and that's what happens. That's what I say has happened, and is surely going to continue to happen. Other factors that I promote are good homemade Arctic food, and a homey atmosphere. (Esther interview 1, protocol page 10, my translation.)

The idea behind the whole concept at Polmakmoen is to provide guests with an integrated package - a package that incorporates both an outer and an inner level. In the interview, Esther emphasizes that the trip to Polmak is a starting point for an inner journey, with wilderness adventures, meditation, healing, Sami shamanism, and self-development courses as boosters. The website proclaims that this is one 'of the most exciting journeys you will ever experience'. ${ }^{9}$ Constructing Polmak as a unique destination paves the way for a variety of experiences and inner development, in contact with nature and in association with a Sami hostess, and a niche product thus takes shape that has value in today's market.

9 http://www.polmakmoen-gjestegard.no/index.html, accessed 01.02.2011. 


\section{Spiritual Entrepreneurship at Polmakmoen Guesthouse}

Esther is thus what I will call a 'spiritual entrepreneur', blending business activities with her religious vision and life project. The marketing of Polmakmoen Guesthouse echoes the ideas of the contemporary experience economy. Here tourists and conference participants are offered 'slow and spiritual experiences' - experiences connected to relaxation, recreation and inner self-development based on close contact with Sami culture and wild nature. ${ }^{10}$ The Guesthouse provides a number of offerings that exist in the borderland between indigenous tourism, the concept of 'slow', spa, wellness and pilgrim tourism. ${ }^{11}$ Polmakmoen is a flexible enterprise, built around a concept that can be adjusted and extended for diverse groups of customers. Visitors thus can combine mountain hiking with healing, or they might just go hunting, relax and enjoy Esther's homemade cooking.

For guests interested in a deep spiritual experience, Esther provides two packages. The first is an individual healing session, where Esther uses a pendulum and crystals to help guide patients in the right direction. For groups of over eight persons, Esther also arranges a course in self-development, titled 'The day is yours - how to reach your inner powers'. This course, she stresses, is particularly suitable for groups who need new surroundings to learn more about themselves. In addition she offers distance healing by phone or email, and claims to have healed a whole football team and to have clients from all over the world.

The spiritual packages at Polmakmoen can be linked to what Lars Ahlin (2007) recognizes as the classic New Age discourse: self-spirituality, self-authority, self-accountability and holism. In our conversation, Esther constantly emphasizes that the self is a divine entity in man, and absolute sovereign with regard to assessments and choices. She sees illness as a sign that something is wrong with the whole person, and as a therapist Esther interprets her role as supervising and guiding, while the patient herself is responsible for doing the job of getting well.

10 The market for tranquillity, relaxation and well-being which often is mixed with spiritual metaphors is huge and very varied, but as Tom O'Dell emphasizes, this is also a phenomenon that has been largely overlooked in the literature on the Experience Economy (O'Dell 2005, 30). 11 The pilgrim concept is under development. Esther's idea is that pilgrims should follow the tracks of the Sami herders. The pilgrim route is planned along the stretch where the reindeer previously moved from winter to summer pasture - from inland to the coast: in this case, from Polmak to Kjølnes in Berlevåg, where Esther also runs the Kjølnes lighthouse resort. 
Esther is also concerned with her resort's spiritual energies. Both in the interview and on the website, Polmakmoen Guesthouse is portrayed as a site at which special powers or energies are gathered and as a place particularly suitable for healing and self-development. Esther advertises her guest resort as a power center to which people should go to obtain energy, to connect to the spiritual side of life, and to experience personal development and growth.

The idea that selected locations have more energy than others has been growing within the New Age field in recent years (see Fonneland 2010). Northern Norway is no exception. At the 'alternative markets' arranged annually in cities all across the region, northern Norway is marketed as a particularly spiritual area. with a wild, powerful landscape. The steep mountains, plains, the proximity to Sami sacrificial sites, the midnight sun, the polar night and the northern lights are qualities that are highlighted as distinctive to the region. It was also here that the Sami pre-Christian specialist, the noaidi, had his home and performed his spiritual tasks, and the landscape is interpreted as to bear traces and imprints of what once was (Fonneland 2007). The highlighting of the northern Norwegian region and Sámi culture must be viewed in context with other developments in the New Age field. Since the 1990s a strong interest has little by little emerged in indigenous people, indigenous lifestyles and indigenous places. This interest has become increasingly pervasive, and today it characterizes a wide cross-section of the New Age orientations (Geertz 2004).

Although Esther's business can be located at the core of what is usually characterized as New Age, her spiritual offerings are not marketed as New Age. Both in the interview and on the homepage, global and recognizable New Age ideas and trends are colored by local Sami culture and traditions. Healing with a pendulum and crystals is presented as Sami shamanism, and self-development courses are marketed on the basis of local place energies and ancient Sami traditions. This localization is able to deflect the criticism, leveled by both researchers and media critics, that the New Age movement is a commercialized fake. By promoting local culture and local Sami traditions, Polmakmoen appears as an alternative and as a contrast to the New Age field. Here the local is emphasized against the national and international, and 'the different' - that which stands out from the mainstream market, while at the same time being similar enough to create interest - has increasing value in the competition for tourists' attention. 


\section{Indigenous Spirituality}

Esther can be located in the religious landscape of late modernity - inspired both by New Age thinking and by her father's traditional relation to the spirits of nature. This type of spirituality can be seen as a form of 'indigenous spirituality' - a late-modern term in international discourse that constructs the world's indigenous peoples as people with a common colonial past, common religious heritage and a spiritual relationship with nature and their surroundings (Christensen \& Kraft 2010, 1). This representation of indigenous people as a community with shared religious values relating to nature, to the past and to traditions of the past can be traced back to 1960s counterculture, and in particular to the interplay between the environmental movement and the New Age movement. These movements emerged within the same period, and have been exchanging ideas ever since, especially in terms of consciousness about ecology and fascination with the world's indigenous peoples. As several researchers have pointed out, these values are also often expressed by indigenous people themselves, in their identity constructions, in the struggle for political rights and in cultural revitalization processes (see Beyer 1998; Kalland 2003; Kraft 2009). 'Indigenous spirituality' is thus a global discourse which attributes a particular kind of spirituality to indigenous peoples, while indigenous people are also able to contribute to the shaping of this discourse and to utilize it for their own strategic purposes.

The creation of identity typically relies on the creation of opposites. Identity processes are framed by dichotomies and borderlines, and are always relational. The term 'indigenous spirituality' is in many ways a cultural marker defined by a contrast to Western society, western religions and western world views (Christensen \& Kraft 2010, 2). Thus when the Sami people were incorporated into the international indigenous movement and into global discourses concerning indigenous spirituality, a political, cultural and religious contrast was constructed between Sami and Norwegians. While the Sami are portrayed as a primitive people living in harmony with themselves and their surroundings, Norwegians are viewed as participating in the opposite - in a hectic modern western society. Values relating to nature and to the landscape mark a distinction between a place-oriented, peaceful, holistic, traditional, and eco-friendly indigenous culture and a modern western capitalist society (see Kraft 2009, 188). This also makes indigenous cultures, as symbols of the opposite of the West, coveted in the tourist market. As researchers have underlined, at the heart of the tourist industry and the new economy lies a quest for what is different, and one 
of the primary narratives in the tourism industry concerns precisely the relationship between the modern and the traditional (see Wang 2000; Olsen 2006, 38; Viken 2000, 29; Kirshenblatt-Gimblett 1998).

Esther is a significant contributor to an emerging Sami indigenous spirituality. This spirituality is at the core of her personal narratives, of her self-understanding and of the product she markets at Polmakmoen. The opening scene in the advertisement video on Polmakmoen Guesthouse's website further highlights the role of this discourse as a marketing tool. Here we meet a Sami man singing the yoik. He looks out over the Finnmark plateau, and takes us to an old Sami sacrificial stone where he ritually hands over a piece of reindeer meat to his forefathers, saying: 'Nature has given us this as a loan. With thanks we give nature back its share'. Further along in the promotional video, we meet men and women dressed in traditional Sami clothes, the kofte, gathered around the fire in a traditional Sami tent, the lavvo. We see white snow-covered landscape, herds of reindeer, and people traveling in the countryside enjoying activities such as fishing, hunting and berry picking. The special character of the destination is strongly linked to experiencing nature, an exotic culture, local food and entertaining narratives. The video illustrates an inner and outer tranquillity, far from the bustle of the city, where the landscape and activities surrounded by nature invite one to experience inner peace. During the ten minutes that the video lasts, a picture is established of the Sami as a people living in harmony with their surroundings and in close contact with the traditions of the past, and underlines that visitors coming to Polmak will be able to experience and take part in the same values themselves.

The commercial relationship at Polmakmoen is presented as characterized by intimacy. Visitors' meetings with their Sami hostess are clearly meant to contribute beneficially to their inner, personal development. Here, tourists are not just tourists or anonymous customers; instead, they are able to become part of a homelike atmosphere that goes beyond a routine tourist scenario. Tourists coming to Polmakmoen are being invited into an indigenous community, and by this means to taste magic and holism of nature. ${ }^{12}$ In this context, indigenous spirituality is presented as a unique product that adds value to a vacation destination by telling a different story and representing a unique experience far removed from daily western life. The communication of an indigenous spirituality can here be seen as a powerful instrument for creating strong and persuasive experiences.

12 http://www.polmakmoen-gjestegard.no, accessed 01.03.2011. 


\section{Envisioning a new Business Community}

In our conversation, Esther emphasizes that when Polmakmoen was turned into a tourist, healing and conference centre her spiritual helpers told her that her second task was to take part in the creation of a new business community and to help change the ideas and perspectives of people in key business positions. Esther's vision for Polmakmoen Guesthouse thus goes beyond being a destination for vacationers and conference participants. Her hope is that the personal, spiritual and cultural experience she offers her guests will impact at a higher, political level, and contribute to the development of a new economic era:

Esther: I got a message relating to what kind of people who would come to Polmakmoen. My helpers told me that I would be working with the top floor in Norwegian politics, business and industry. They were to come here and get new ideas related to the new knowledge that is reflected in the Age of Aquarius which we entered about twenty years ago. And it was the people at the top floor who needed this knowledge first, to be able to change their thinking. And above all things I was told that I should participate in building a new business community, and I was forced to wonder: 'Should I work with the new business community, I who have zero bearing on economics?' But later I have found out that this is exactly why, because if I had been an economist I would have had too much ballast with me from all the things that should not be with us anymore. So I have since been commissioned to use what I have built up here to bring the new business community into reality. (Esther interview, protocol page 2, my translation.)

As Aupers and Houtman emphasize, New Age spirituality has taken root within the public domain of business organizations, and courses focusing on spirituality are held for the purpose of promoting both well-being and efficiency - in happiness and profit (Aupers \& Houtman 2006, 211-4). Polmakmoen Guesthouse is used as a site for conferences and courses by firms such as Statoil and Volvo, by the Norwegian Government as represented by some of its ministries, and by the Norwegian Sami Parliament. Even if they do not take part in organized New Age courses, these firms and politicians are all introduced to Esther's standard repertoire concerning her spiritual experiences in developing Polmakmoen Guesthouse. For these and other visitors, Esther says she wants to be a mediator - a bridge between the normal and the paranormal, between human beings and spiritual powers, in order to bring about a new business community based on the values of a 
Sami indigenous spirituality: values relating to spirituality, to a pre-modern local Sami society and to 'slow money' - to the exchange of gifts and services rather than money exchange :

Trude: But when you talk about the new business community, what's the core of it?

Esther: It is that we'll work out a business that is driven by the joy of creating non-profit. It is creativity, not money, that you should have as the core in everything you do when you build something up. For it is not that we shall be without money, for one or other means of exchange we need. And that's fine, money does have value. But I think we will see a development toward exchanging goods and services. (Esther interview 1, protocol page 12 , my translation.)

Esther's visions about changing the current business community are related to her experiences in developing Polmakmoen Guesthouse. The first years were marked by economic uncertainty, and the Guesthouse's bankruptcy in 2004. Esther was subsequently able to buy the resort back, and these experiences created the seed for what Esther today proclaims as the core values in the new economy. On several occasions Esther has lectured on this topic, and relates it to the development of a creative rural economy and to a new sustainable northern Norwegian region.

To create a package that is both appealing and believable, in the interview and on the website, Esther walks a fine line between a rational and a spiritual worldview. To survive in the tourist market and to be able to take part in changing the business community, she argues, you cannot focus on spirituality alone. She stresses that, by inheriting both her mother's and her father's qualities, she has a foot in the rational as well as in the spiritual world. Though a well-known healer, Esther never takes part in the popular alternative markets mentioned above; and by keeping a distance from the most iconic New Age marketplaces, she can be said to maintain a seriousness that is required in the tourist industry. Her focus on the rational also serves to counter and to play with national myths describing people in the northern region as both 'noble' and as 'ignoble savages' (see Mathisen 2010). The balance between the spiritual and rational in the marketing of Polmakmoen creates credibility and strengthens Esther's role as an entrepreneur in the tourist market.

Through the Sami slogan 'ale moraš', Esther's goal is to reshape both her visitors and the business community. These words encapsulate the 
values that she perceives as fundamental for a new economic era and a new industrial life to develop for the best, both for the individual and for the environment. In the process of bringing the message of 'ale moraš' to the world, Esther even recruited President Barack Obama as one of her helpers. When the President was awarded the Nobel Peace Prize, Esther knew she had to go to Oslo to give him the words her grandmother had been telling her. Dressed in her Sami kofte, with a small handmade lavvo of reindeer skin with the slogan 'Ale moraš' neatly embroidered in silver, she took off to the capital to greet the president. The lavvo was handed over to the Nobel Institute and later given to Obama himself. The case was taken up by local and national media, and Esther thus had the opportunity to convey her message through $\mathrm{TV}$, radio, and the press.

Just how much people change, if at all, after their visit to Polmakmoen, is uncertain, and beyond my focus in this article. In the interview it thus remains unclear how the relaxation of key business people in the tranquil environment of Polmak, and the loosening of their ties to the modern world, can trigger a real change in the business community; what is significant is how Esther promotes this as a central value of the location, and that the media has become involved in this marketing.

\section{Spiritual Entrepreneurs and Media}

The New Age universe with which Esther became familiar during the early nineties has, from the very beginning, been criticized as overly interested in money and overly market-oriented. Especially in the media, there has been a tendency to create an image of New Age entrepreneurs as concerned only with economic gain. But with Esther this comes out differently. Both in the local and national media, she is portrayed and celebrated as a courageous entrepreneur full of ideas and energy, who has helped put Finnmark on the economic map (see Nordlys 17.10.2010; Finnmark Dagblad 23.07.2010; VG 15.02.2009). In the newspaper Finnmark Dagblad we can read:

Esther Utsi is a driven woman in the travel industry in eastern Finnmark. She runs both Kjølnes lighthouse and Polmakmoen Guesthouse. And the number of this year's visitors has been overwhelming. (Finnmark Dagblad 23.07.2010, my translation.)

Esther has also several times been nominated for the title 'Finnmark Personality of the Year', and has won awards for her entrepreneurial activities. This 
positive attention is in stark contrast to how Sami neo-shamans have been greeted in the Sami core areas (see Fonneland 2010). Even though parts of her business overlap with the way neo-shamans operate, their healing practices and courses, in contrast to Esther's, are met with suspicion and hostility. As pointed out by Kraft, this can be seen as a manifestation of a post-colonial conscience, which has led to increased caution about the media's portrayals of indigenous people (Kraft 2011). My argument is also that the positivity surrounding her is connected to the distance she keeps from the New Age market, both through her remote geographical location (Finnmark being far away from the New Age core area), and through her deliberately linking of the marketing of spirituality to Sami local traditions.

Esther's two sources of inspiration, New Age and Sami indigenous spirituality, have come to symbolize two different sets of values. In a market and media context, Esther's latest inspiration, New Age, is often characterized as lacking roots in tradition - as fake; and New Agers are pictured as insincere, preposterous, and naïve. Indigenous spirituality, on the other hand, seems to enjoy a positive image, associated with values such as wisdom, the ancient, heritage, environmental protection and knowledge about nature (Kraft 2009). When, on the website, healing with crystals and pendulums are transferred from their New Age context and presented as a natural part of a Sami pre-Christian religion, here known as Sami shamanism, this can be seen as a move to enhance the attractiveness of the product, and to maintain a distance between the traditional and the modern. By keeping a distance from the typical New Age markets and by connecting the site's religious aspects to Sami culture more than to New Age, Esther increases Polmakmoen Guesthouse's significance in the tourist industry. In contrast to the perceived shallowness of the New Age, the link to a Sami past and Sami indigenous spiritual traditions offers a strikingly distinctive brand, and projects assurance of a unique product, experience or service.

The staging of Sami indigenous spirituality involves more than selling a vacation destination. The relatively frequent and consistently positive media attention that Esther has received also makes her spiritual enterprise at Polmakmoen a central actor in regional development processes. ${ }^{13}$

13 A search for Esther Utsi in the database A-tekst which contains editorial articles from more than 50 Norwegian newspapers resulted in 101 hits. 


\section{New Senses, New Stories - Concluding Remarks}

Through the selection of symbols and stories that Esther presents to her guests, Polmakmoen Guesthouse is cast as a vacation destination that is also a portal to a magical world where untamed nature and spirituality are central values. The location in a rural environment, and contact with Sami culture, are projected as generating internal growth and development. But the story of Polmakmoen Guesthouse is also a story about politics and about a woman who, using her remote location as a starting point, wants to reform the world community.

Tourism includes both politics and power. As Michael Hall argues:

Despite its common consumer association with pleasure and leisure, perhaps as far away from politics as one can get in the popular mind, tourism does not occur in a political vacuum. In fact few subjects better illustrate the political dimensions of tourism than the issues associated with indigenous tourism. Whether it be decisions as to where tourism development occurs or more humanistic concerns associated with commodification and representation of heritage and identity, tourism is political. (Hall 2007, 306.)

Though Polmakmoen Guesthouse is a place of relaxation and well-being, it is also a place in which the local and global are intertwined, and where power relations are played out, political interests are materialized, cultural identities are contested and dreams are redefined. The story of power and politics which is illustrated through my conversation with Esther can be seen in the context of a whole raft of cultural events and projects in northern Norway in recent years. Both the Mandela concert, held in Tromsø June 2005, and Tromsø's application for the Winter Olympics in 2014/2018, point toward a common aim shared with that we can glimpse in Esther's story (see Kraft 2008; Guneriussen 2008). In different ways, they all involve replacing the traditional image of northern Norway as a pre-modern rural community with new and powerful stories with spiritual undertones.

In late modernity, the construction of local and specific identities positions people, products and services as particularly valuable and authentic. This is a positioning that allows adaption to a global world and at the same time opens up responses and opposition (Robertson 1992; Featherstone 1995; Beyer 1998). Globalization and communications technology make it possible for local communities to relate to other places in the world and to create networks that cross national borders. This is also a process where new narratives about the local community's culture and history occur: 
narratives that challenge familiar notions of what is central and what is peripheral. Though not necessarily denying a position as peripheral, the juggling with symbolic representations can be said to counter hierarchical relations from within. At this point places that have so far been peripheral in a national context, such as northern Norway, are made central in global stories (see Granås 2009).

It is precisely this transformation of the northern Norwegian landscape that Esther reveals in our interview. By assigning a local community values as spiritual, magical, and mythical, as well as rational, Esther's story challenges established representations in which northern Norway represents the peripheral, and is economically, ethnically and culturally marginalized. The intellectual balance of her representation, and the distance she maintains from the iconic New Age markets, contradict the image of Finnmark as an uncivilized outpost of modernity. At the same time, they point to values of a spiritual character which the Western community is lacking, values that Esther argues are central in contemporary economic processes for setting a new business community in motion.

On 24 February 2011, Esther was a key guest on the TV show 'Svendsen om Hansen og Jensen' on TV2, one of Norway's largest national TV channels, a show which sets out to investigate whether myths about people in the different regions of Norway match reality. This broadcast discussed myths related to the Sami, and the fact that most Norwegians have the impression that all Sami are reindeer herders and that they are rough and superstitious. The TV host, Truls Svendsen, took a trip to the Finnmark plateau to check out the myths, and here he visited, among other places, Polmakmoen Guesthouse.

At Polmakmoen, Esther gave Truls a lecture about her visions for her guest resort. The TV host also participated in a healing session in Esther's healing room decorated with Indian dream catchers. After the meeting with Esther, the myth that Sami are superstitious was examined, and revised: no longer presenting Sami people as superstitious, but rather, as spiritual, in a positive sense.

In the TV show Esther was presented as a representative for all Sami, thus casting the Sápmi region or nation as exotic and spiritual. To a national audience of TV viewers, the Sami people were in one turn 'de-mythicized' as superstitious, and 're-mythicized' as spiritual. The change in mythical content also implies a change in status and power. Spirituality was here seen as being performed as a resource, not as an emblematic stigma locating the Sami population outside modern life and development (see Mathisen 
2010). From being seen as outside civilization, the landscape of the Sami was presented as a center - with Esther and her spiritual business at Polmakmoen as the context.

The fact that the Sami culture has become part of an international indigenous community where discourses about indigenous spirituality are part of the symbolic repertoire has considerable consequences for how the Sami culture is staged in the tourist industry. Polmakmoen Guesthouse is a clear example of such new marketing and communication of Sami as indigenous, where words like spirituality, holism, harmony, closeness to nature and a mythological past are central themes. As a spiritual entrepreneur, Esther's mission here is to showcase Finnmark as a country of resources, rich in delicate ingredients, great scenery, lighting, colors and not least, spiritual energies. With the Sami slogan 'Ale moraš', Esther also wants to make Finnmark a site for innovative change in economics and business - a small handmade lavvo in the White House symbolizing the big step from periphery to center.

\section{Bibliography}

\section{Ahlin, Lars}

2007 Krop, sind-eller ånd?. Alternativve behandlere og spiritualitet i Danmark. Højbjerg: Forlaget univers.

\section{Alver, Bente Gullveig}

1999 Det magiske menneske. Magi som perspektiv for identitetsarbejde. - Bente Gullveig Alver et al., Myte, Magi og Mirakel. I møte med det moderne, 147-64. Oslo: Pax Forlag AS.

2011 Fortælling, fortolkning, fortryllelse. Et kulturanalytisk perspektiv på fortælletraditionen om den kloge. - Din, tidsskrift for religion og kultur $1-2,132-54$.

\section{Alver, Bente Gullveig \& Torunn Selberg}

1992 Det er mer mellom himmel og jord. Folks forståelse av virkeligheten ut fra forestillinger om sykdom og behandling. Sandvika: Vett \& Viten AS.

\section{Aupers, Stef \& Dick Houtman}

2006 Beyond the Spiritual Supermarket: The Social and Public Significance of New Age Spirituality. - Journal of Contemporary Religion 21 (2), 201-22. 


\section{Beyer, Peter}

1998 Globalization and the Religion of Nature. - J. Pearson \& G. Samuel (eds), Nature Religion Today. Paganism in the Modern World, 11-21. Edinburgh: Edinburgh University Press.

\section{Birch, Maxine}

1996 The Goddess/God Within: The Construction of Self-Identity through Alternative Health Practices. - Kieran Flanagan \& Peter C. Jupp (eds), Postmodernity, Sociology, and Religion, 83-100. London: Macmillan.

\section{Bowman, Marion}

2007 Magiske reiser og magiske steder. - Ingvild Sælid \& Siv Ellen Kraft (eds), Religiøse reiser. Mellom gamle spor og nye mål, 53-62. Oslo: Universitetsforlaget.

\section{Christensen, Cato \& Siv Ellen Kraft}

2010 Religion i Kautokeino-opprøret. En analyse av samisk urfolksspiritualitet. - Nytt norsk tidsskrift 01, 19-27.

\section{Dawson, Michael \& John Bellamy Foster}

1996 Virtual Capitalism: The Political Economy of the Information Highway - Monthly Review 49 (3), 40-57.

\section{Featherstone, Mike}

1995 Undoing Culture. Globalization, Postmodernism and Identity. London: Sage Publications.

\section{Fonneland, Trude}

2010 Samisk nysjamanisme. I dialog med (for)tid og stad. Doktoravhandling: Universitetet i Bergen.

2007 Med fokus på det nære og lokale. Tromsø - ein samisk urfolksby? Din, tidsskrift for religion og kultur 1, 79-88.

\section{Geertz, Armin}

2004 Can We Move Beyond Primitivism? On Recovering the Indigenes of Indigenous Religions in the Academic Study of Religion. - Jacob K. Olupona (ed.), Beyond Primitivism. Indigenous Religious Traditions and Modernity, 37-70. New York: Routledge.

\section{Guneriussen, Willy}

2008 Modernity Re-enchanted: Making a 'Magic' Region. - Jørgen Ole Bærenholdt \& Brynhild Granås (eds), Mobility and Place. Enacting Northern European Peripheries, 233-44. Aldershot: Ashgate.

\section{Granås, Brynhild}

2009 Constructing the Unique - Communicating the Extreme Dynamics of Place Marketing.- Torill Nyseth \& Arvid Viken (eds), Place Reinvention. Northern Perspectives, 111-25. Farnham \& Burlingtion: Ashgate. 


\section{Hall, Michael}

2007 Politics, Power and Indigenous Tourism. - Richard Butler \& Tom Hinch (eds), Tourism and Indigenous Peoples, 305-18. Oxford: Elsevier.

\section{Hammer, Olav}

2001 Claiming Knowledge. Strategies of Epistemology from Theosophy to the New Age. Leiden, Boston \& Köln: Brill.

\section{Hess, David J.}

1993 Science in the New Age: The Paranormal, Its Defenders and Debunkers, and American Culture. Madison, Wis.: University of Wisconsin Press.

Hinch, Tom D.

2004 Indigenous Peoples and Tourism. - Alan A. Lew \& Allan M. Williams \& Colin Michael Hall (eds), A Companion to Tourism, 246-57. Malden: Blackwell.

\section{Honoré, Carl}

2004 In Praise of Slow: How a Worldwide Movement is Challenging the Cult of Speed. SanFrancisco: HarperSanFrancisco.

\section{Jensen, Rolf}

1999 The Dreamsociety. How the Coming Shift from Information to Imagination will Transform your Business. New York: McGraw-Hill.

\section{Johnston, Alison M.}

2006 Is the Sacred for Sale? Tourism and Indigenous Peoples. London, Sterling, VA: Earthscan.

\section{Järvinen, Margaretha}

2005 Interview i en interaktionistisk begrepsramme. - Margaretha Järvinen \& Nanna Mik-Meyer (eds), Kvalitative Metoder I Et Interaktionistisk Perspektiv. Interview, observationer og dokumenter, 27-48. København: Hans Reitzels Forlag.

\section{Kalland, Arne}

2003 Environmentalism and Images of the Other. - H. Selin (ed), Nature Across Cultures. Views of Nature and the Environment in Non-Western Cultures, 1-17. Amsterdam: Kluwer Academic Publishers.

\section{Kirshenblatt-Gimblett, Barbara}

1998 Destination Culture. Tourism, Museums, and Heritage. California: University of California Press.

\section{Kraft, Siv Ellen}

2007 En senmoderne pilegrimsreise. Prinsesse Märtha Louise og Ari Behns fra hjerte til hjert. - Ingvild Sælid Gilhus \& Siv Ellen Kraft (eds), Religiøse reiser. Mellom gamle spor og nye mål, 39-50. Oslo: Universitetsforlaget. 
2008 Place-Making through Mega-Events. - Jørgen Ole Bærenholdt \& Brynhild Granås (eds), Mobility and Place. Enacting Northern European Peripheries, 219-31. Aldershot: Ashgate.

2009 Sami Indigenous Spirituality. Religion and Nation Building in Norwegian Sápmi. - Temenos. Nordic Journal of Comparative Religion 45 (2), 179-206.

2011 Hva er nyreligiøsitet? Oslo: Universitetsforlaget.

\section{Löfgren, Orvar}

2003 The New Economy: a Cultural History. - Global Networks 3, 239-54.

\section{Löfgren, Orvar \& Robert Willim}

2006 Introduction. The Mandrake Mode. Orvar Löfgren \& Robert Willim (eds), Magic, Culture and the New Economy, 1-18. Oxford \& New York: Berg Publishers.

\section{Mathisen, Stein R.}

2010 Indigenous Spirituality in the Touristic Borderzone. Virtual Performances of Sámi Shamanism in Sápmi Park. - Temenos. Nordic Journal of Comparative Religion 46 (1), 53-72.

\section{Mossberg, Lena}

2007 At skabe oplevelser ved hjælp af storytelling. - Jørgen Ole Bærenholdt \& Jon Sundbo (eds), Oplevelses Økonomi. Produktion, forbrug, kultur, 321-40. Fredriksberg: Forlaget Samfundslitteratur.

\section{Mulcock, Jane}

2001 Creativity and Politics in the Cultural Supermarket. - Continuum 15 (2), 169-86.

\section{O'Dell, Tom}

2005 Spas: The Cultural Economy of Hospitality, Magic and the Senses. Lund: Nordic Academic Press.

\section{Olsen, Kjell Ole Kjærland}

2006 Making Differences in a Changing World: The Norwegian Sami in the Tourist Industry. The Touristic Construction of the 'Emblematic' Sámi. - Scandinavian Journal of Hospitality and Tourism, 6 (1), 37-53.

\section{Partridge, Christopher}

2004 The Re-Enchantment of the West vol.1. Alternative Spiritualities, Sacralisation, Popular Culture and Occulture. London: Routledge.

Pine, Joseph B. \& James H. Gilmore

1999 The Experience Economy. Boston: Harvard Business Scholl Press.

\section{Ray, Larry \& Andrew Sayer}

1999 Culture and Economy after the Cultural Turn. London: Sage. 


\section{Redden, Guy}

2005 The New Age: Towards a Market Model. - Journal of Contemporary Religion, 20 (2), 231-46.

\section{Robertson, Roland}

1992 Globalization: Social Theory and Global Culture. London: Sage Publications.

\section{Selberg, Torunn}

2011 Pilegrimsveien som kulturarv: Den norske pilegrimsrenessansen. Din, tidsskrift for religion og kultur, 120-31.

\section{Stausberg, Michael}

2011 Religion and Tourism: Crossroads, Destinations and Encounters. London \& New York: Routledge.

\section{Thrift, Nigel}

2006 Making Sense: An Afterword. - Orvar Löfgren \& Robert Willim (eds), Magic, Culture and the New Economy, 131-6. Oxford \& New York: Berg Publishers.

\section{Viken, Arvid}

2000 Turismens essensialiserende effekt - samisk kultur i lys av en tiltakende turisme. - Stein R. Mathisen (ed.), Kulturens Materialisering: Identitet og Uttrykk, 25-52. Kristiansand: Høyskoleforlaget.

\section{Wang, Ning}

2000 Tourism and Modernity: A Sociological Analysis. Amsterdam: Pergamon.

Weber, Max

1930 The Protestant Ethic and the Spirit of Capitalism. Translated by Talcott Parsons. London: Unwin University Books.

\section{Internet Sources}

Polmakmoen Gjestegård, http://www.polmakmoen-gjestegard.no, accessed February 02, 2011.

Samitour, http://www.samitour.no/english/2-overnatting.html, accessed March 03, 2011.

Newspaper Articles

Nordlys 17.10.2010.

Finnmark Dagblad 23.07.2010.

VG 15.02.2009.

\section{Empirical Sources}

Interview with Esther Utsi 15 of November 2010. 
Appendix. Image 1. Polmakmoen Guesthouse. Photo Trude Fonneland.

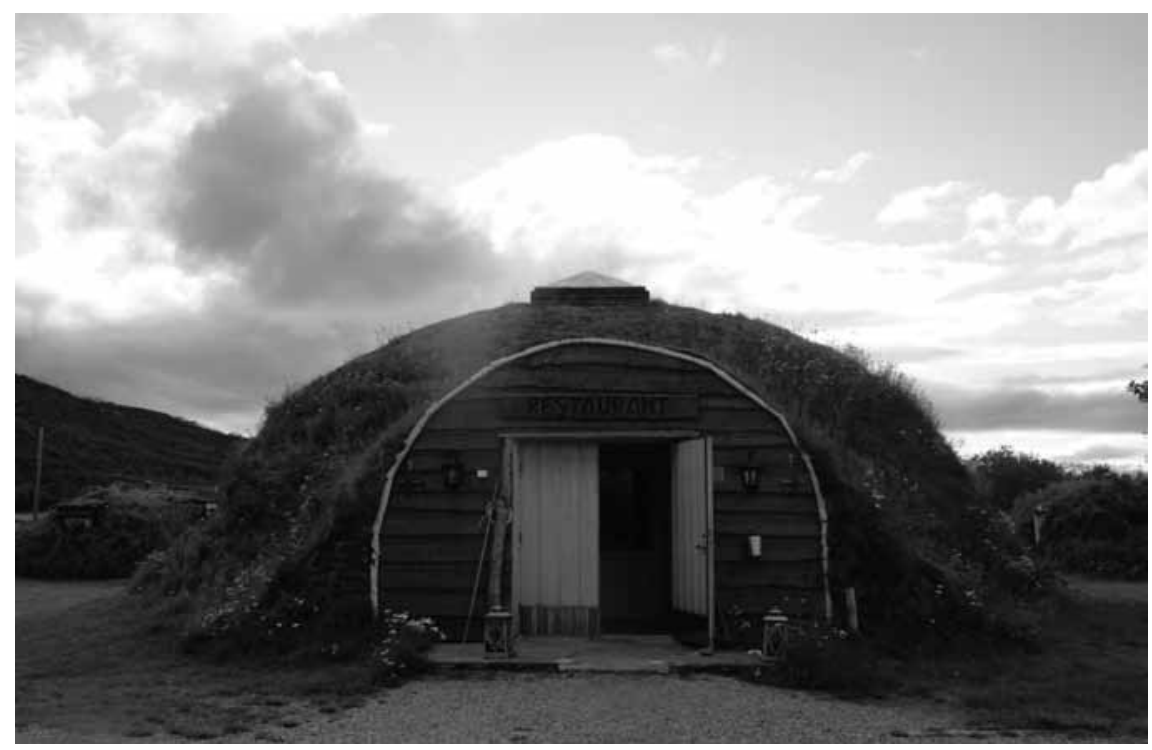

